\title{
TESOL Classroom Observations: A Boon or a Bane? An Exploratory Study at a Saudi Arabian University
}

\author{
Sayyed Rashid Shah \\ Faculty of Engineering, King Abdul-Aziz University, Jeddah, Saudi Arabia \\ Khalid Al Harthi \\ English Language Institute, King Abdul-Aziz University, Jeddah, Saudi Arabia
}

\begin{abstract}
The present study aimed to explore the EFL teachers' perceptions of classroom observation system implemented in an English Language Institute of a Saudi university. It reviewed literature on the nature of instructional supervision and classroom observation to develop an understanding of different types of classroom observation and various contextual issues related to the practice teacher evaluation through observation. The current research utilised semi-structured interviews to elicit qualitative data from five purposively chosen EFL instructors. The participants shared their lived experiences of the research phenomenon in great detail that resulted in wholesome data on the subject. The findings, presented in six overarching themes, reveal the psychological plight of the teachers as they considered the practice of classroom observation a consistent professional challenge due to several factors, i.e. their lack of autonomy in pre and post-observation conference, observer-observee trust deficit, observers' subjective approach towards the assessment criteria and classroom teaching, observers' insufficient training and qualifications, the use of observation as a means to control teachers, and the element of threat and insecurity. Based on the findings, recommendations are set forth to improve the existing observation system for the benefit of the teachers, learners and the institute.
\end{abstract}

Index Terms—instructional supervision, classroom observation, teachers' challenges, EFL context

\section{INTRODUCTION}

Professionalism, a contested issue in educational circles around the world, is equally desirable in the field of ELT. Teachers' professionalism is primarily assessed, keeping in view teachers' professional competence, skills and effectiveness as classroom teachers, through instructional supervision (Farmer, 2006). More often than not, teachers are lambasted for their students' underachievement and poor quality of teaching and learning in classrooms. Generally, this criticism emanates from the comments of those who are responsible for teachers' supervision and classroom observations. Contrary to the principles of teacher learning and professional development, classroom observations, actually meant for teachers' professional growth, are usually more evaluative and less developmental in nature, leading to teacher burn-out and less-effective performance in classrooms. Worse still, there is a strong perception of the element of coercion and threat in the whole process. Similar to various other contexts, in the Arab World too, classroom observations are regarded as threatening and ineffectual due to their subjective, judgmental, and impressionistic nature (Mercer, 2006). Lacking autonomy and voice, teachers often resent the process of observation, and consider the observers unjustifiably powerful personnel who is there to judge and pass verdicts on their teaching practices.

Instructional supervision, formative in scope, aims at improving teachers' skills (Zepeda \& Kruskamp, 2007). Hinchey (2010) argues that supervision 'is used to gain information that can help teachers, even those who are already proficient, to improve or expand their abilities' (p. 6). In the light of literature, supervision has two main objectives: a) collecting data on teacher performance through various means (formal and informal observation), and b) linking that data to professional development of teachers (Zepeda, 2007). With a formative approach, feedback provided to teachers in post-supervision period focuses on developing performance and is not linked with evaluation. The feedback includes descriptive data gathered during observations (Ovando, 2005). On the contrary, evaluation aims to rate the teachers' performances in a bid to decide reappointments, terminations, or pay-scales (Hinchey, 2010; Zepeda, 2007). The literature has highlighted three distinct foci related to teacher evaluation: a) rating teachers on their professional traits, b) rating teachers on instructional practices, and c) rating teachers based on their professional growth and specific classroom traits (Ovando \& Ramirez, 2007). In present scenario, both in western and non-western contexts, evaluation has focused on assessing teacher performance based on demonstration of targeted teaching practices and specific skills.

In EFL and ESL contexts, instructional supervision, 'one of a number of ways of improving professional practice' (Metcalfe, 2006, p.449) is mainly used as a yardstick to evaluate both novice and experienced teachers' competence and skills. As found by O'Leary (2012) in British education system, in Saudi Arabia, instructional supervision in the form of 
classroom observation is a ubiquitous mechanism in teachers' professional lives, used as a means of collecting data about what goes on in classrooms through box-ticking exercise, based on which judgements about teachers' performance, skills and competence are made. This judgmental approach towards classroom observation makes it difficult to create a culture of collaboration, acceptance and constructive criticism. Moreover, using the box-ticking exercise and grading system have given rise to a range of counterproductive consequences that negatively impact the professional identity of the teachers (O'Leary, 2012). Similarly, Shah et al. (2013) found that the element of threat in the Saudi EFL context is presumably due to the uncomplimentary nature of evaluation which has implications for classroom teaching. The current study in this particular sense will attempt to explore the EFL teachers' perceptions of classroom observation as instructional supervision and its implications on their practices in the Saudi context. The findings of the study will hopefully raise the consciousness of the administrators and observers about the classroom observation related issues. To this end, research at hand attempts to answers the following three research questions:

1. What are the EFL teachers' perceptions of classroom observations in their work context?

2. To what extent is the current observation system a challenge for the EFL teachers?

3. What are the factors that make classroom observations a challenge in the present context?

\section{LITERATURE REVIEW}

This section presents a concise review of literature on the scope of classroom observation. Firstly, it defines classroom observation and considers its various roles in teacher education. Secondly, it surveys inherent challenges faced by educators in other contexts and highlights various issues related to different types and goals of classroom observations. Finally, it looks into the practice of classroom observations in the domain of ELT/TESOL.

\section{Classroom ObServation}

In the late 1960s, teachers welcomed administrators, supervisors and observers to their classrooms for formal, informal or peer observation (Bernstein, 2008; Gosling, 2002). As an integral part of summative evaluation, classroom observations are 'those operations by which individuals make careful, systematic scrutiny of the events and interactions occurring during classroom instruction. The term also applies to the records made of these events and interactions' (Cogan, 1973, p.134). These events and interactions are recorded for several purposes, i.e. for teacher annual evaluation, for teacher professional development and learners' performance assessment.

Scholars perceive classroom observations as a valuable tool which is employed to understand classroom realities and achieve high standards of effective teaching methodologies. The most recent work by Murphy (2013) highlights various aspects of classroom observation. For instance, it offers an opportunity for supervisors to assess teachers' styles, their classroom management skills and various aspects of teaching that are hard to obtain through other forms of evaluation. Moreover, it allows teachers to receive constructive feedback on their teaching techniques and methods in a bid to improve them further. In a nutshell, it is one of the most common ways of reflecting on pedagogical practices (Farrell, 2011), which can help teachers evaluate their strengths and weaknesses.

The observation schemes applied in the education mainstream and ELT field have typically two procedures: the topdown procedure which is designed and implemented by experts mostly external and far removed from classroom realities; the bottom-up procedure which is initiated and carried out by teachers with collegial collaboration in their institutions (Lasagabaster \& Sierra, 2011). However, in some contexts teachers are not frequently observed since classroom observations are considered a source of discomfort, anxiety, and stress both for in-service and pre-service teachers, and a subjective approach that aims to question and judge teachers' professional competence (Borich, 2008).

\section{A. Issues with Classroom Observation}

Authors associate several issues with the process and implementation of classroom observations. Williams' (1989) concern is that traditional observations '...often cause problems for teachers and trainers. They tend to be judgemental, relying on a trainer's subjective judgements, rather than developmental, developing the teacher's ability to assess his or her own practices' (p.85). One of the major causes of these problems is the observers' lack of professional training as very few language teachers ever receive any formal training to carry out such crucial responsibilities (Sheal, 1989; Bailey, 2006). Literature indicates that the implementation of observation standards and procedures often differ across observers in various contexts, culminating in their giving, at times, inadequate feedback to observes, which accentuates the importance of professional training on part of the observers for effective and reliable outcomes of the process (Murphy, 2013).

Most teachers around the world despise the practice of classroom observation as the idea of being observed causes stress, nervousness and anxiety (Aubusson et al., 2007; Borich, 2008). Moreover, the whole practice is perceived as a way of surveillance and control rather than a means to professional development (Metcalfe, 2006). Li (2009) has also highlighted the fact that teachers feel anxious being observed as they see observers using top-down authority and looking at classroom affairs subjectively. As a results, teachers' reservations and concerns have given space to articles with titles such as 'Survive teacher observations' (Sasson, 2008) and put the observer-observee relationship in question. 
Observer-observee relationship is the key to a successful show of an observed lesson and it should not look like a private cold war between the two parties (Bailey, 2006). However, a strong relationship is dependent on the level of trust they share (Cranston, 2009). A strong bond and good relationship between the observer and observee will not only benefit the teacher, but the observer as well. With a positive learning attitude, observation will support the observer to capture the classroom events precisely and objectively and go beyond the recording of mere impressions (Wajnryb, 1992). Also, it will review the collected data collaboratively to ensure positive outcomes, initiate a useful dialogue about teaching strategies, and identify future foci for the observer and observee (Murdock, 2000). Further, it will gather "valid, objective, and recorded" data (Hunter, 1983, p. 43) that will explicitly discuss classroom events rather than personal impressions (Murdock, 2000). This process will offer the observers an opportunity to consistently observe teachers and give them feedback (Shannon, 1991). Moreover, frequent observations over an extended period of time will improve the reliability (Denner, et al., 2002) and increase the validity of the observation system (Cronin \& Capie, 1986). Zepeda (2007) further elucidates the role of observers and supervisors by categorising them as visionary instructional leaders. The observers' vision is a combination of knowledge, reality, experiences, pedagogical beliefs, and human values, which adds to the importance of providing feedback to instructors (Zepeda, 2007) and 'provides a tangible representation of effective instructional planning and delivery' (DiPaola \& Hoy, 2008 p. 10). Furthermore, the classroom observers' vision helps them develop skills to interlink supervision, professional development, and evaluation that result in teacher growth (Green 2010).

\section{B. Types and Goals of Observations}

\section{Appraisal observations}

The process of appraisal observation is seen as 'supervision' in educational circles. The term "general supervision" (Wallace, 1991, p.108) refers to outside the classroom, whereas "clinical supervision" (Wallace, 1991, p.108) encompasses the idea of practices within classrooms. In terms of clinical supervision, it is considered a special occasion when an observer is sitting at the back of the classroom observing and recording the teachers and learners' actions (Wajnryb, 1992). The underlying assumption is that observation is a powerful tool that enables participants to gather data and gain insights into the classroom teaching and learning (Mackey \& Gass, 2005). Moreover, it needs to represent an impartial and unbiased view of the observer. Although observers are required to ensure non-involvement (Gebhard, 1999), their presence may cause frustration and consequently impact the classroom dynamics (Wajnryb, 1992).

\section{Developmental observations}

Williams (1989) asserts that classroom observation should be "developmental rather than judgmental" (p. 85) and should provide teachers with opportunities to raise their awareness of classroom dynamics, improve their abilities to assess their own teaching approaches and develop their skills to notice, reflect and enhance their pedagogic skills (Malderez, 2003).

Sidhu and Fook (2010) have placed clinical supervision in the humanistic evaluation model that consists of five stages which lead to developmental observations: i) in pre-observation stage, the observer and observee collaboratively plan a formal observation session; ii) in while-observation stage, the observer gathers low-inference and verifiable data; iii) in post- observation scenario, the observer analyses the data to discover strengths and weaknesses; iv) in postobservation meeting, observer and observee collaboratively focus on both the strengths and weaknesses to help teachers develop a future plan of action that will help the them grow professionally; and v) afterwards, both the parties set a time-frame to achieve the set targets. In a similar way, Malderez (2003) mentions four main purposes of classroom observations; for professional development, for training, for evaluation, and for research. Likewise, Lasagabaster and Sierra (2011) cite three main forms of observations; for professional development, for rewards, and for promotion. Notwithstanding its drawbacks cited in the literature, researchers and practitioners have consensus that the most effective goal of classroom observation is professional development (Montgomery, 2013).

In ideal circumstances, an observation is often preceded by a 'planning conference' in which the scope, nature and expectations of observation are explained, and are followed by a 'feedback conference' in which observation findings are discussed and used to identify areas for development and improvement (Gall \& Acheson, 2010). In the case of postobservation dialogue, it helps promote observer-observees' collaboration since 'posing questions to teachers during these interactions allows them to engage in reflection, to think critically, and to approach teaching as a decision making process' (Vasquez \& Reppen, 2007, p. 164).

In sum, to make the observation scheme successful and beneficial for the teachers, the observers need to be qualified trainers who know what to look for, how to provide effective feedback and how to keep the subjectivity factor to a minimum. Moreover, observation needs to be a 'non-judgemental description of classroom events that can be analysed and given interpretation' (Gebhard, 1999, p.35) in feedback discussions which are integral to teacher professional development.

\section{Classroom Observation in ELT}

In different contexts, the role and objectives of classroom observation are perceived differently, and thus the experiences of classroom observation among pre-service and in-service teachers differ a great deal (Wang \& Day, 2002). The aim of observation in pre-service TESOL training is to use it as a learning tool for potential ESOL teachers to learn the basics of teaching (Gebhard, 1999; Wajnryb, 1992). On the other hand, in public sector, classroom observations 
have become synonymous with teacher evaluation and teacher supervision (Sahakian \& Stockton, 1996). While the significance of observation is acknowledged around the world, there is dearth of research on its goals and ways of implementation in different EFL/ESL contexts. Generally, challenges faced by teachers with observation systems are identical in nature. For instance, Wang and Day (2002) found both subjective and procedural problems with observation practices which affect observer-observee relationship and minimise the role of teachers to submissive performers. Similarly, other studies conducted in ELT contexts rate observation schemes ineffective and judgmental due to the observers' lack of professionalism and their inability to frequently revisit the same classroom in order to record teachers' progress on a long term basis (Copland, 2008; Hooton, 2008; Mallows, 2002; Murdoch, 2000; Tennant, 2006; Howard, 2010; Borg, 2006).

In the context of Middle East, teacher evaluation does not take place in a supportive and congenial environment (Murdoch, 2000). The findings of a study conducted at the United Arab Emirates University (UAEU) show that the tools used for teacher evaluation are often under-developed and 'ad-hoc', and observations are mainly carried out by overburdened director supervisors who give no sufficient time to prepare for, and follow up on classroom visits. Such ad-hoc evaluation practices often result into teacher burn-out, anxiety and a lack of faith in the validity of observation (Murdoch, 2000). In the same way, Howard (2010) explored various aspects of teacher appraisal and the impact of classroom observation on learners and teachers' behaviour in an observed lesson in UAE context; however, this study is the very first attempt to investigate the burning issue of classroom observation in Saudi EFL context.

\section{CONTEXT OF THE STUDY}

The current study is conducted in the English Language Institute (ELI) of a Saudi university. The ELI runs the Preparatory Year Programme (PYP) catering to the English language learning needs of about 6000-7000 students each year. The faculty of the ELI comprises around 200 language teachers from 25 different countries with various L1 backgrounds. The PYP consists of four modules with seven weeks each. In each module, a level-based student textbook and workbook are covered following a weekly pacing guide. Ahead of the enrollment in the PYP, students have to take the Oxford Placement Test designed by the University of Oxford following the Common European Framework (CEF) which helps stream the students into suitable levels starting from Beginner (A0) to Intermediate (B1). After successful completion of a module, students are promoted to another level. The ELI has adopted the New Headway Plus (Special Edition) as main syllabus resource.

The ELI has adopted a rigorous system of teacher evaluation which grades teachers on a scale of 1 to 5. The lowest grades which are 1and 2 may result in teachers' termination or transfer to remote satellite campuses. As part of annual evaluation, bi-annual classroom observations are carried out for each teacher. During classroom observation, teachers' instructional skills are assessed using a box-ticking rubric. These skills are divided into 16 categories covering a range of teaching aspects: effective use of classroom space and teaching resources, rapport with learners, classroom management skills, lesson delivery and execution of plan, and linguistic competence of a teacher. Moreover, the rubric considers the lesson components and its flow, i.e. warm up, effective instructions, monitoring, feedback and assessment, effective questioning, varied learner's centred activities, subject knowledge, and the timing and pace of the lesson.

\section{METHODOLOGY}

The current study is naturalistic and exploratory in nature, considering the experience, perceptions, and multiple socially constructed realities of EFL teachers at a Saudi Arabian university. To understand how the EFL teachers perceive the phenomenon of classroom observation in their context and how it has challenged their professional skills, an interpretive paradigm was adopted to underpin this inquiry. The interpretive research paradigm reflects naturalistic, constructivist, and qualitative features (Robson, 2002). Smith (1987) argues that 'for interpretive approaches, the object field to be studied is the acts and meanings ascribed to events by actors in a particular social context' (p.140). This correlates with Marshall and Rossmans' (1999) argument that 'for a study focusing on individual lived experience, the researcher could argue that one cannot understand human actions without understanding the meaning that participants attribute to these actions, their thoughts, feelings, beliefs, values, and assumptive worlds' (p. 57).

The motivation for this inquiry came from our personal experience of classroom observation the Saudi EFL context. The difficulties and challenges we observed and encountered in the current evaluation and observation system motivated us to look into the teachers' dilemmas of classroom observation in their contexts. Although our role in this study served as investigators, we found ourselves immersed in the interviewees' comments and empathised with their pedagogic quandaries. Borg and Gall (1983) state that 'by being actively involved in the situation that the researcher is observing, the researcher often gains insights and develops interpersonal relationships that are virtually impossible to achieve through any other method' (p. 26).

\section{A. Method of Data Collection}

The aim of the qualitative data analysis was to achieve a thorough understanding of the target phenomenon, and to this end the current study utilised qualitative techniques for data collection (Jupp, 2006). Five semi-structured interviews were conducted to explore the perceptions of EFL teachers about classroom observation as part of 
instructional supervision. The choice of qualitative interviews was made since it is "a uniquely sensitive and powerful method for capturing the lived experiences and lived meanings of the subjects' everyday world" (Kvale, 2007, p. 11). From a researcher's standpoint, the main objective to utilise interview techniques in a qualitative study is 'to seek indepth understanding about the experiences of individuals and groups, commonly drawing from a small sample of people, selected purposively. Such types of interviews are called semi-structured' (Scott \& Usher, 2006, p. 147). Moreover, semi-structured interviews were used for their flexible structure which allowed the interviewees to express their viewpoint freely (Flick, 2002). Also, it offered us the opportunity to develop unexpected themes which emerged during the interviews (Cohen et al., 2011; Mason, 2002). For the purpose of this study, open-ended questions, probes and prompts were mainly written in the light of the literature reviewed on the topic, however some questions, probes and prompts were framed based on our personal experience, intuition and observation of the target phenomena.

Five interviews were conducted in the English language with five EFL instructors. Each interview took approximately 40 to 50 minutes. All the interviews were audio recorded, transferred to and saved on a passwordprotected computer. For each interview, an MS-Word file was created with the pseudonyms of the interviewees, which are cited in the findings.

\section{B. Participants}

Five participants took part in this study. They were interviewed at their convenience. The selected participants were all English language instructors in a Saudi Arabian University from English and non-English speaking countries. We used the Purposive Sampling strategy (Patton, 2002) in order to access teachers who were ranked 'excellent' on the rubric applied by the Professional Development Unit (PDU) at the ELI. The participants had a minimum 5 years of EFL teaching experience in the Saudi context. Purposive sampling paved our way for seeking thorough information from those experienced instructors who were in a strong position to divulge it (Cohen et al., 2011).

Considering the research ethics, the participants' informed consent to participate in the study was obtained, and they were communicated their right to withdraw from the research at any time. Furthermore, the anonymity and confidentiality of their views were guaranteed by giving them a chance to choose their pseudonyms (Neuman, 2006).

\section{Data Analysis}

Data analysis included open coding (Miles \& Huberman, 1994, Creswell, 2012). We used Nvivo software to organise and examine the interview data more efficiently. After entering the interview data in Nvivo software, we read the interviewees' responses and assigned them 29 open codes. Later, we merged the identical codes and reduced them to 20. We then re-examined the codes several times in the light of the data to ascertain that the assigned codes matched the content. Throughout the coding process, we kept looking for additional codes and remained focused on the research questions (Miles \& Huberman, 1994; Newby, 2010). Later, the codes were collapsed into 12 categories and various subcategories. As we incessantly examined the generated codes and categories, there emerged six over-arching themes. The findings section contains a description and discussion of these six major themes which inform the main research questions.

\section{FINDINGS AND DISCUSSION}

As the participants recalled experiences of how the phenomenon of classroom observation has challenged their professional skills and what factors have contributed to make it a challenge in the ELI context, this section renders a detailed account of their lived experiences and informs the three research questions.

\section{A. Teachers' Lack of Autonomy in Pre and Post-observation Conference}

The assumption that feedback is integral to instructional improvement draws from research on formative assessment. However, if teachers can express themselves and reflect on their strengths and weaknesses in post-observation session of evaluative observation, it can add to their professional growth (Jonson, 2008). Teachers in this study have raised their voice about their lack of autonomy in pre and post observation conferences where they receive 'a blue print' from the observers with no choice to comment or disagree (Wallace, 1991, p. 110). Being passive participants in the whole process, they are not given a choice to teach a topic; rather observers decide what to teach in an observed lesson. This often results in teacher demotivation and burnout as they lack autonomy and power to make decisions about their classroom teaching. Moreover, the patronising attitude of the observers puts the validity of observation in doubt. Bailey (2006) believes that successful observations are those which 'are both preceded and followed by discussions with the teacher, but those communications don't always occur' (2006, p. 146) due to the imbalance of power relationship which needs to be recognised as a reality (Wragg, 1999). Similar to Cockburn's claim 'the observer is commonly perceived as possessing greater power', which 'is legitimised by organisational arrangements' (2005, p. 384). In post-observation meeting, in case of disagreement or objection over the observers' decisions, observees usually avoid to question their verdicts rather accept what is set forth as they do not want to risk their jobs. It explicates the effect of power imbalance on the observees' participation in the feedback conference (Chamberlin, 2000) and undermines the developmental potential of the whole process. 
I don't necessarily agree with the observers'feedback and point of views, I do express myself, but at the end nothing happens. They believe that they are always right and teachers are always wrong. They never change their opinion (Joseph).

I express myself in the feedback stage, I give the observer my points. Sometimes he agrees but it doesn't make much difference. So it's better not to argue as arguments can result into big administrative issues and teachers can lose their jobs (Ali).

The above quotes unveil the suppressive nature of the observation process for the observees who refrain from expressing their opinions. They seem to be dealing with stubborn observers who enjoy excessive authority to pass their verdicts on teachers' professionalism. In such circumstances where teachers are not given proper feedback and consider the feedback as 'one man show', it becomes difficult to consider the developmental aspects of the observation practice.

\section{B. Observer-observee Lack of Trust}

The imbalance of power relationship leads to the teachers' lack of trust in the observer's role as the latter enjoys excessive authority to give judgments on teachers' 'one shot' performance that may not be adequate to assess the potential of a teacher. In order to optimise maximum benefits of the observation schemes, establishing a congenial relationship with observees becomes vital as observation must be built on a foundation of trust (Lasagabaster \& Sierra, 2011), otherwise, the lack of trust will lead to suspicions and doubts. Furthermore, the uneven state of affairs between the observer and observee is seen as a tug of war due to which participants in this study find it impossible to discuss their weaknesses while reflecting on their lesson in post-observation conference (Bailey, 2006).

The element of trust is certainly not there. The observers do not trust the teachers. They should show trust in the teachers' skills. They should not underestimate teachers. In order to be positive, observers should be trainers first, they should have a good teaching experience. They should first teach here and acquire good background knowledge of the Saudi context (Michael).

Generally, the observers at the ELI are known for their partial or impartial approach. Teachers often consider the observers as powerful figures who can freely say whatever they want and make you feel helpless and hapless. Of course, I never believe what they say or write in the feedback session (Ali).

I believe the observers often give the management a different view of the teachers' performances. I would say the written or verbal feedback is only a formality and they often change their opinion. Sometimes, they change their already written feedback and inform the teachers as well, but teachers can't do anything about their verdicts (Rajun).

It can be inferred from the above quotes that observers and management have a pre-assigned agenda. The objective may not be to facilitate teachers' professional development, rather use the system as a tool to determine teachers' future in the institute. Consequently, teachers often lack trust in the observers and give no weightage to their feedback. Moreover, their feedback is taken as biased and unreliable.

\section{Observers' Subjectivity}

The environment of mistrust finds its roots in the observers' subjectivity, a commonly found phenomenon in other contexts too (Borich, 2008). EFL teachers at the ELI consider the observers' approach subjective and different from one another since they see things through their own lenses and give their diverged opinions about a universal aspect of language teaching. Wragg (1999) in his seminal work An Introduction to Classroom Observation, raises the issue of reliability of observation as a form of assessment and remarks that 'we often "observe" what we want to see' (p. vii). His comment highlights the subjectivity of observation schemes and how various events are 'inevitably filtered through the interpretive lens of the observer' (Foster, 1996, p. 14). In a similar way, teachers in this study have conveyed their point that the varied interpretations of the observation rubric add to the teachers' frustration as the assessment criteria are subjectively construed by the observers.

Generally the observations at the ELI are subjective and there is no harmony between the observers' understanding of the rubric. The rubric has 15 points and I am sure all the observers look at them from 15 different angles (Shaan).

Subjectivity is something that you never get rid of and it negatively affects your teaching. However, here at the ELI the observers' bossy attitude and inordinate authority make it a big issue (Rajun).

\section{Lack of Training and Irrelevant Qualification of the Observers}

In a typical top-down management and centralised educational system, the carefully chosen people to perform certain duties are often very close to their bosses. The management expresses more trust in their chosen coordinators, supervisors and observers who are responsible for teacher assessment and evaluation, rather than teachers who hold the key to the students' success. In such scenarios, observers' qualifications make no difference as classes are often observed by those who are not only from other departments, but have no ELT experience whatsoever. This trend is indicative of unprofessional attitude that has a long lasting effect on teachers' motivation and job commitment. The observers' only qualification is the 'trust' of the boss, which invariably adds to the stress of the teachers. Since, they lack experience, training and qualification in the field of language teacher education, their comments and feedback often sound ridiculous.

My classes were observed by those who had no ELT qualification and experience. They followed a rubric, however, they would always look for negative points. Their feedback would irritate me (Michael). 
Similar to what Namaghi (2011) found, untrained and unqualified observers with no basic knowledge of teacher training and classroom observation make the teachers' lives difficult. It affirms the fact that language teachers are usually promoted to key positions, i.e. observers and supervisors without receiving any formal training (Bailey, 2006). Consequently, their presence in classroom causes nervousness and frustration that lead to burnout and demotivation.

The observer's qualification is a core thing. I should be aware of who is coming to my class. I should know of his experience and training. To me it is very important whether he knows TESOL methodologies or not, does he have ELT background? (Joseph).

It is very important to know about the observer's background, if he doesn't have an ELT background and he is going to observe me I don't think that he will understand the dynamics and the objectives of the different activities I introduce in my class, and he will not be able to grade my lesson accordingly; so, I would rather prefer a person who is qualified, who knows about ELT and who has done some kind of teacher training courses and who knows something about classroom observation. If he is qualified, I will find myself easy and I will teach confidently (Ali).

The observers' qualifications, relevant teaching experience and teacher training experience should be shown to the teachers that he is well-read and has attended courses because such things play a very big role in observation. Regarding classroom observation, there is a lot of stuff they need to know about (Shaan).

The above quotes value the observers' training, qualification and experience as language teachers and teacher trainers. Hence, teachers have emphasised the need to induct observers with substantial teacher training qualifications, adequate knowledge of the teaching context and solid understanding of the learners' needs at the ELI. Adherence to these properties will help teachers not to feel the pressure, rather develop their faith in the system and teach more efficiently in a conducive environment.

\section{E. Control and Accountability}

In many contexts, classroom observation is still a challenge and a threat to the teachers' professional identity due to which it has become difficult to move towards a collaborative culture in which observation practice is accepted as a routine task between colleagues and where it is seen as one of a number of ways of improving professional practice. Ozga (1995) considers the 'shifting relationships between the state and professionals' and the increasing importance of 'management' in a marketised system (p. 23). On these grounds, the management aims to achieve maximum outcomes by increasing control and accountability in the guise of professionalism. For this reason, teachers regard classroom observations as a system of surveillance and control (e.g. OFSTED inspections) rather than as a means of promoting professional development. In fact, the whole process results into the deprofessionalisation of the teachers. In a nutshell, the findings suggest that there is a lack of congenial relationship between the instructors and management and the latter keep a very close check on them through classroom observations. In order to control the teachers, more often than not, observers, supervisors and academic coordinators are given inordinate powers to follow and report the teachers' oncampus activities. Teachers also believe that the academic coordinators and observers have their own vested interests to secure their positions and thus show their loyalty to the management and that results in teacher exploitations.

Observation is not the only way to keep a close check on the teachers. They try to control the teachers in many different ways; however, classroom observation is typically used for contract renewal purposes (Michael).

These middle managers and observers who assess our performances are more than efficient in showing their loyalty to the management by spying on teachers and reporting petty things. They are definitely not teacher friendly (Shaan).

\section{F. The Element of Threat and Insecurity}

Owing to the aforementioned concerns and reservations of the teachers, the element of threat and coercion prevail at the ELI that affects teachers' performances and students' outcomes particularly in an observed lesson. Furthermore, factors such as lack of autonomy, subjectivity, teachers-observers' trust deficit and the observers' lack of training contribute to the teachers' anxiety, stress and insecurity. Surprisingly, these common traits of the twentieth century found by Williams (1989) and Quirke (1996) still exist in Saudi EFL context, due to which teachers, mostly expats, consider the observation scheme a challenging phenomenon.

To be honest, it really is a threat. I always feel nervous and it is never a very good experience for me. I really have to be very careful about it. When I get the date, there is a fidgety feeling (Rajun).

Teachers have been fired, transferred and put under check all due to classroom observation. In fact, classroom observation decides your future as a teacher (Ali).

One small mistake that may be a pronunciation or grammatical slip of tongue, can result into my sacking or transferring to other campuses. There is no job security (Shaan).

The above quotes expose the failure of administration in a bid to provide a conducive professional environment where teachers could discharge their duties with confidence. Moreover, it is seen that teachers' voices are imprisoned in their classrooms and they have no right to express their concerns.

\section{RECOMMENDATIONS}

The current observation scheme represents an observer-dominated model that is run by undertrained and lessqualified observers. Owing to the subjective approach of the observers and the policy of surveillance on the teachers, 
there is a climate of threat and insecurity. In such a scenario, teachers feel stressed, demotivated and unnerved, and thus fail to perform well in their classrooms, which in turn affects the whole learning process. Therefore, the teacher evaluation system needs to be overhauled. For the effective operation of the system, management needs to gain the confidence of the teachers. Their autonomy and job security need to be assured and the observers or supervisors' role and interference in teachers' classrooms have to be curtailed. In this highly competitive professional context, well qualified and professionally trained observers should be assigned the task to observe classes with utmost objectively. This approach will lead to a professional environment where teachers and observers will share the bond of trust and work towards the common goal: the betterment of the students, their own professional development, and the image of the institute. From the researchers' perspective, there is a serious need for more critical work on the teachers' professional autonomy, empowerment, and voice.

\section{CONCLUSION}

The present study has attempted to explore the perceptions of EFL teachers about the classroom observation system prevalent in an English language institute. The findings have revealed the psychological plight of the teachers as they have experienced enormous challenges linked to the practice of classroom observations as part of their annual evaluation. Teachers consider classroom observation a perennial pressure due to various reasons, i.e. their lack of autonomy in pre and post-observation conference, observer-observee lack of trust, observers' subjective approach towards the assessment criteria and classroom teaching, observers' insufficient training and qualification, the use of observation as a means to control teachers, and the prevailing element of threat and insecurity. Similar to what O'Leary (2006) believes, the observation scheme at the research site offers an inequitable proportion of control and decision making to the observer while limiting the role of the observee to a passive recipient. In such a situation, it would be too optimistic to consider the current observation scheme as a learning tool since the research findings have highlighted a number of inadequacies in its design and implementation.

\section{REFERENCES}

[1] Aubusson, P., Steele, F., Dinham, S., \& Brady, L., (2007). Action learning in teacher learning community formation: informative or transformative? Teacher Development, 11(2), 133-148.

[2] Bailey, K. M. (2006). Language teacher supervision: A case-based approach. Cambridge University Press.

[3] Bernstein, D. J. (2008). Peer review and evaluation of the intellectual work of teaching. Change: The Magazine of Higher Learning, 40(2), 48-51.

[4] Borg, S. (2006). Teacher cognition and language education: Research and practice. London, UK: Continuum.

[5] Borich, G.D. (2008). Observation skills for effective teaching. Upper Saddle River, NJ: Pearson Merrill Prentice Hall.

[6] Chamberlin, C, R. (2000). TESL degree candidates' perceptions of trust in supervisors. TESOL Quarterly, 34(4), 653-673.

[7] Cockburn, J. (2005). Perspectives and politics of classroom observation. Research in post-compulsory education, 10(3), $373-$ 388.

[8] Cogan, M. L. (1973). Clinical supervision. Boston, USA: Houghton-Mifflin Co.

[9] Copland, F. (2008). Deconstructing the Discourse: Understanding the Feedback Event. In: Garton, S. and Richards, K. eds. Professional Encounters in TESOL. Basingstoke: Palgrave Macmillan: 5-23.

[10] Cohen, L., Manion, L., \& Morrison, K. (2011). Research methods in education. NY, USA: Routledge.

[11] Cranston, J. (2009). Holding the reins of the professional learning community: Eight themes from research on principals' perceptions of professional learning communities. Canadian journal of educational administration and policy, 90(2), 1-22.

[12] Creswell, J. W. (2012). Qualitative inquiry and research design: Choosing among five approaches. London, UK: Sage.

[13] Cronin, L., \& Capie, W. (1986, April). The influence of daily variation in teacher performance on the and validity of assessment data. Paper presented at the Annual Meeting of the American Educational Research Association.

[14] Denner, P. R., Miller, T. L., Newsome, J. D., \& Birdsong, J. R. (2002).Generalizability and validity of the use of a case analysis assessment to make visible the quality of teacher candidates. Journal of Personal Evaluation, 16(3), 153-174.

[15] DiPaola, M. F., \& Hoy, W. K. (2008). Principals improving instruction: Supervision, evaluation, and professional development. Pearson/Allyn and Bacon.

[16] Farmer, F. (2006). Accountable professional practice in ELT. ELT Journal, 60(2), 160-170.

[17] Farrell, T. S. C. (2011). 'Keeping SCORE': Reflective Practice Through Classroom Observations. RELC Journal, 42(3), 265272.

[18] Flick, U. (2002). Qualitative research-state of the art. Social science information, 41(1), 5-24.

[19] Foster, P. (1996). Observing schools: A methodological guide. London, UK: Chapman.

[20] Gall, D., \& Acheson, K. A. (2010). Clinical Supervision and Teacher Development. NJ, USA: John Wiley \& Sons.

[21] Gebhard, J, G., \& Oprandy, R. (1999). Language teaching awareness: A guide to exploring beliefs and practices: Cambridge University Press.

[22] Goldstein, J. (2007). Easy to dance to: Solving the problems of teacher evaluation with peer assistance and review. American Journal of Education, 113(3), 479-508.

[23] Gosling, D. (2002). Models of peer observation of teaching. Generic Centre: Learning and Teaching Support Network. Retrieved, 8(10), 08-10.

[24] Green, E. (2010). Building a better teacher. New York Times Magazine, 1-9.

[25] Gunter, H, M. (2002). Teacher appraisal 1988-1998: A case study. School leadership \& management, 22(1), 61-72. 
[26] Hooton, N. K. (2008). The design of post--observation feedback and its impact on student teachers. Professional encounters in TESOL: Discourses of teachers in teaching, 24-41.

[27] Howard, A. (2010). Is there such a thing as a typical language lesson? Classroom Discourse, 1(1), 82-100. doi: $10.1080 / 19463011003750699$.

[28] Howard, A. (2010). Teacher appraisal: the impact of observation on teachers' classroom behaviour. University of Warwick.

[29] Hinchey, P. H. (2010). Finding freedom in the classroom (Vol. 24). Peter Lang.

[30] Hunter, M. (1983). Script-taping: An essential supervisory tool. Educational Leadership, 41(3), 43-44.

[31] Jackson, A. (2013). Teacher Evaluation: An International Perspective. http://blogs.edweek.org/edweek/global_learning/2013/03/teacher_evaluation_an_international_perspective.html (Retrieved on 10 October 2013).

[32] Jonson, K, F. (2008). Being an effective mentor: How to help beginning teachers succeed: Corwin-volume discounts.

[33] Jupp, V. (2006). The Sage Dictionary of Social Research Methods. SAGE Publication Ltd. London.

[34] Kleinhenz, E., \& Ingvarson, L. (2004). Teacher accountability in Australia: Current policies and practices and their relation to the improvement of teaching and learning. Research papers in education, 19(1), 31-49.

[35] Kvale, S. (2007). Doing Interviews. London: Sage.

[36] Lasagabaster, D., \& Sierra, J, M. (2011). Classroom observation: desirable conditions established by teachers. European Journal of Teacher Education, 34(4), 449-463. doi: 10.1080/02619768.2011.587113.

[37] Li, Y. (2009). The perspectives and experiences of Hong Kong preschool teacher mentors: implications for mentoring. Teacher Development, 13(2), 147-158.

[38] Mackey, A., \& Gass, S. (2005). Second language research: Methodology and design. Mahwah NJ: Lawrence Erlbaum.

[39] Mallows, D. (2002). Non-linearity and the observed lesson. ELT journal, 56(1), 3-10.

[40] Malderez, A. (2003). Observation. ELT Journal, 57(2), 179-181.

[41] Marshall, C., \& Rossman, G, B. (2010). Designing qualitative research. London, UK: Sage.

[42] Mercer, J. (2006). Appraising higher education faculty in the Middle East: leadership lessons from a different world. Management in Education, 20(1), 17-18.

[43] Metcalfe, Christopher. (1999). Developmental classroom observation as a component of monitoring and evaluating the work of subject departments in secondary schools. Journal of In-Service Education, 25(3), 447-459. doi: 10.1080/13674589900200088.

[44] Mercer, N. (2000). Words \& Minds: how we use language to work together: London: Routledge.

[45] Miles, M., B, \& Huberman, A. M. (1994). Qualitative data analysis: An expanded sourcebook. CA, USA: Sage.

[46] Montgomery, D. 2002. Helping teachers develop through classroom observation . 2nd ed. London: David Fulton.

[47] Murdoch, G. (2000). Introducing a teacher-supportive evaluation system. ELT Journal, 54(1), 54-64.

[48] Murphy, R. (2013). Testing teachers: what works best for teacher evaluation and appraisal. Improving Social Mobility Through Education. The Sutton Trust.

[49] Namaghi, S, O. (2011). Theorizing Language Teachers' Perceptions of the Rationales and Methods of Classroom Observation. US-China Foreign Language. David Publishing, Vol. 9( No. 3, 147-157).

[50] Neuman, W, L. (2006). Social research methods: Qualitative and quantitative approaches . US: Pearson Education: Inc.

[51] Newby, P. (2010). Research methods for education. Harlow, UK: Pearson Education Ltd.

[52] O'Leary, M. (2006). Can inspectors really improve the quality of teaching in the PCE sector? Classroom observations under the microscope. Research in Post-Compulsory Education, 11(2), 191-198. doi: 10.1080/13596740600768984.

[53] O'Leary, M. (2012). Exploring the role of lesson observation in the English education system: a review of methods, models and meanings. Professional Development in Education, 38(5), 791-810. doi: 10.1080/19415257.2012.693119.

[54] Odhiambo, G, O. (2005). Teacher appraisal: the experiences of Kenyan secondary school teachers. Journal of Educational Administration, 43(4), 402-416.

[55] Ovando, M, N. (2001). Teachers' perceptions of a learner-centered teacher evaluation system. Journal of Personnel Evaluation in Education, 15(3), 213-231.

[56] Ovando, M. N., \& Ramirez Jr, A. (2007). Principals' instructional leadership within a teacher performance appraisal system: Enhancing students' academic success. Journal of Personnel Evaluation in Education, 20(1-2), 85-110.

[57] Ozga, J. (1995). Deskilling a Profession: Professionalism, deprofessionalism and the new managerialism'in H. Busher and R. Saran (eds.) Managing Teachers as Professionals in Schools.

[58] Patton, M. Quinn. (2002). Qualitative interviewing. Qualitative research and evaluation methods, 3, 344-347.

[59] Quirke, P. (1996). Using unseen observations for an in-service teacher development programme. The Teacher Trainer, 10(1), $18-20$.

[60] Ramirez, A., Lamphere, M., Smith, J., Brown, S., \& Pierceall-Herman, J. (2011). Teacher development and evaluation: a study of policy and practice in Colorado. Management in Education, 25(3), 95-99. doi: 10.1177/0892020610387956.

[61] Richards, JC, \& Burns, A. (2009). The Cambridge Guide to Second Language Teacher Education: New York: Cambridge University Press.

[62] Robson, C. (2002). Real world research: A resource for social scientists and practitioner-researchers (Vol. 2). Oxford, UK: Blackwell Publishers.

[63] Sahakian, P, \& Stockton, J. (1996). Opening Doors: Teacher Guided Observations. Educational Leadership, 53(6), 50-53.

[64] Sasson, D. (2008). Survive teacher observations. training.suite101.com/article.cfm/classroom_observations (Retrieved on 12 July 2012).

[65] Scott, D, \& Usher, R. (2011). Researching education: data, methods and theory in educational enquiry. London, UK: Continuum International Publishing Group.

[66] Shannon, D. M. (1991, February). Teacher evaluation: A functional approach. Paper presented at the Annual Meeting of the sEastern Educational Research Association, Boston, MA.

[67] Sheal, P. (1989). Classroom observation: training the observers. ELT journal, 43(2), 92-104. 
[68] Sidhu, G, K, \& Fook, C, Y. (2010). Formative supervision of teaching and learning: Issues and concerns for the school head. European Journal of Scientific Research, 39(4), 589-605.

[69] Sinnema, C, EL, \& Robinson, V, MJ. (2007). The leadership of teaching and learning: Implications for teacher evaluation. Leadership and Policy in Schools, 6(4), 319-343.

[70] Smith, M, L. (1987). Publishing qualitative research. American Educational Research Journal, 24(2), 173-183.

[71] Shah, R. A., Hussain, M, A., \& Nasseef, O, A. (2013). Factors impacting EFL teaching: An exploratory study in the Saudi Arabian context. Arab World English Journal, 4, 104-123.

[72] Tennant, A. (2006). Key issues in classroom observation. IATEFL VOICES, 191 (8), 8-9.

[73] Vásquez, C, \& Reppen, R. (2007). Transforming practice: Changing patterns of participation in post-observation meetings. Language Awareness, 16(3), 153-172.

[74] Wang, W, \& Day, C. (2002). Issues and Concerns about Classroom Observation: Teachers' Perspectives. http://files.eric.ed.gov/fulltext/ED467734.pdf (Retrieved on 15 August 2012).

[75] Wallace, M, J. (1991). Training foreign language teachers: A reflective approach. Cambridge, UK: Cambridge University Press.

[76] Williams, M. (1989). A developmental view of classroom observations. ELT journal, 43(2), 85-91.

[77] Wragg, E,C. (1999). An introduction to classroom observation. 2nd ed. London, UK: Routledge.

[78] Zepeda, S.J. (2007), The Principal as Instructional Leader: A Handbook for Supervisors, 2nd ed. Larchmont, NY: Eye on Education.

[79] Zepeda, S. J., \& Kruskamp, B. (2007). High School Department Chairs-Perspectives on Instructional Supervision. The High School Journal, 90(4), 44-54.

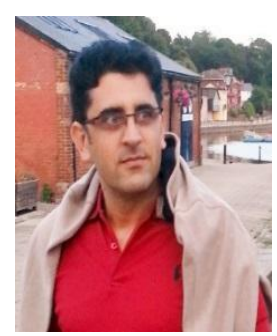

Sayyed Rashid Shah is a lecturer in English at King Abdul-Aziz University, Saudi Arabia. He earned a master degree in TESOL from Sheffield Hallam University, UK. He is currently enrolled on EdD TESOL programme at University of Exeter, UK. Mr. Shah's research interests include language teacher development, educational leadership and management, and EFL classroom teaching and learning.

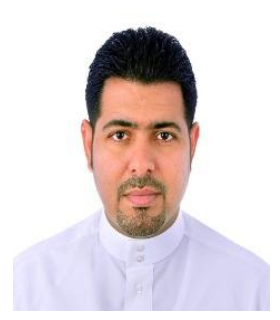

Khalid Al Harthi is Vice-Dean of the English Language Institute at King Abdulaziz University in Jeddah, Saudi Arabia. He is an assistant professor of Applied Linguistics. Dr. Al Harthi was awarded his Ph.D. in Applied Linguistics from New Castle University, UK, in 2012. He obtained his Master's in TEFL from Arizona State University, USA, in 2002. His research interests include student motivation for learning, developing language learning strategies, and the use of modern technology in English classrooms. 